\title{
Study on Antibacterial Root Canal Sealer Containing Chlorhexidine Dihydrochloride
}

\section{Influence of components of a base sealer on its properties}

\section{Toshiyuki NAMBU}

Department of Dental Materials, Research Center for Medical Polymers and Biomaterials, Kyoto University, 53, Shogoin-Kawara-cho, Sakyo-ku, Kyoto

Received on March 31, 1984

The effect of heat treatment of $\mathrm{ZnO}$ and the content of rosin on the setting time and the sealability of zinc oxide-eugenol system as a base material for a new antibacterial root canal sealer were determined. It is concluded that the zinc oxide-eugenol system contained $\mathrm{ZnO}$ heated at $700^{\circ} \mathrm{C}$ and 30 percent of rosin is appropriate for the new antibacterial root canal sealer.

Key Words: Root canal sealer, Setting time, Sealing ability

\section{INTRODUCTION}

The function of a tooth, even if its pulp tissue has been lost by disease or an injury, can be satisfactory maintained for a long time by appropriate treatment for its root canal. A root canal filling material is used in the final step of a series of this root canal treatment. It is considered to be profitable for the success of the treatment that the material possesses antimicrobial activity when it is applied to a root canal which has little protective potential.

In many clinical procedures of this treatment, the vertical or the horizontal condensation method using a point and a sealer as filling materials is performed most widely. As the sealer is attached directly to the tissue in this method, it should have antimicrobial activity. In this study, a sealer belonging to $\mathrm{ZnO}$-eugenol system, such as the preparation suggested by Grossman (Table 1) ${ }^{1}$, is employed for the reason of its wide usage.

In addition, the sealer must satisfy numerous requirements in terms of its properties. For instance, the setting time of this system is affected by the heat treatment of $\mathrm{ZnO}^{2)}$ and

Table 1 Composition of Grossman's root canal
cement


the sealing ability may also changed by this factor. The content of rosin appears to have some effects on the properties of a sealer. To obtain a suitable sealer, the influence of components on the properties of the material was investigated qualitatively or quantitatively in this report.

\section{MATERIALS AND METHODS}

1. Effect of heat treatment of $\mathrm{ZnO}$

1) Influence on the setting time-Several types of $\mathrm{ZnO}$ powder, obtained by heating $\mathrm{ZnO}$ J.P., Japanese Pharmacopoeia, at various temperature, were prepared. In this article the heating temperature is indicated in parenthesis, e.g. $\mathrm{ZnO}(300)$, while unheated $\mathrm{ZnO}$ is expressed as $\mathrm{ZnO}(\mathrm{JP})$. After the treatment all preparations were ground with an automatic mortar and sifted through the sieve $(270$ mesh) to make the particle size uniform.

The setting time of the mixture of these $\mathrm{ZnO}$ powder and clove oil J.P. was determined. The powder/liquid $(\mathrm{P} / \mathrm{L})$ ratio had to be changed for each combination because the apparent specific volume of powder varied considerably with the heating temperature. The standard consistency of mixture was decided as the $\mathrm{P} / \mathrm{L}$ ratio which produced a disk extending $30 \mathrm{~mm}$ in diameter when the mixture is placed between two pieces of glass plate, loaded $240 \mathrm{~g}$ and left in the air for 10 minutes after beginning of mixing (Table 2) According to the procedure defined by JIS for a dental zinc phosphate cement, the setting time was measured with Vikcat's needle $\left(1 \mathrm{~mm}^{2}\right.$ in cross-sectional area and $300 \mathrm{~g}$ in weight) in $37^{\circ} \mathrm{C}, 100 \% \mathrm{RH}$. It was considered that the period from start of mixing to failure of insertion of the needle into the sample corresponded to the setting time.

Table 2 Consistency

\begin{tabular}{cc}
$\begin{array}{c}\text { Heating } \\
\text { Temperature* } \\
\left({ }^{\circ} \mathrm{C}\right)\end{array}$ & $\begin{array}{c}\text { Powder/Liquid } \\
\text { Ratio } \\
(\mathrm{g} / \mathrm{ml})\end{array}$ \\
\hline $\begin{array}{c}\text { Non-heated } \\
300\end{array}$ & 1.6 \\
600 & 2.2 \\
700 & 2.3 \\
800 & 2.5 \\
$>900$ & 3.1 \\
& 5.0 \\
\hline
\end{tabular}

2) Influence on the sealing ability-The sealing ability of a mixture of $\mathrm{ZnO}$ powder used in the previous experiment and clove oil was determined. Many methods have been adopted for the investigatoin of the sealing ability of filling materials $s^{3 \sim 5)}$. In this report the sealing ability was estimated by means of the dye penetration test using a glass model for the purpose of reducing the experimental error.

The model, presented schematically in Fig. 1, was composed of two pieces of slide glass, the surface of which partially roughened by sand-blasting uniformly, binding together with a cover glass $(0.2 \mathrm{~mm}$ in thickness) as a spacer. After the sample was placed in this space, two long sides of the model were sealed with wax to permit the dye to penetrate 

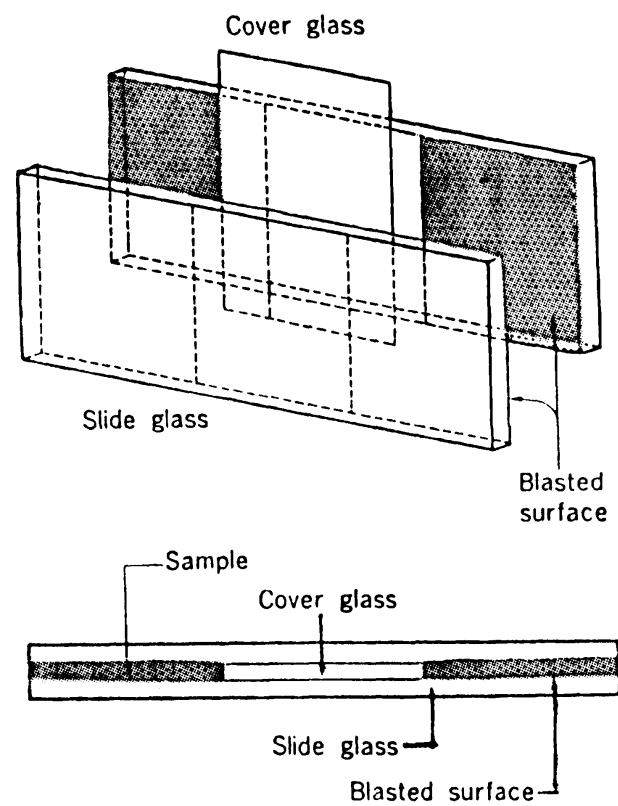

Figure 1 Schematic diagram of specimen used in the dye penetration test

from the short ends. The specimen was immersed in $0.1 \%$ methylene blue solution for 7 days at $37^{\circ} \mathrm{C}$. At the end of the immersion period, the depth of dye penetration was measured. This method facilitates the measurement because the front of the penetration is detected as a line parallel to the open end of the model. In addition, preparing the sample in the form of a film conserves the amount of sample and is relevant to the clinical application of a root canal sealer.

\section{Effect of content of rosin}

1) Influence on the setting time-The mechanism of setting of the $\mathrm{ZnO}$-eugenol system, including the sealer adopted in this report, is based on the chelating reaction between $\mathrm{ZnO}$ and eugenol. However, rosin may also affect this mechanism to some degree. A series of blends of $\mathrm{ZnO}(700)$ and aliquots of $5 \%$ of rosin powder (passed through 270 mesh) ranging from $0 \%$ to $50 \%$ was prepared. The setting time of the mixture of these blends and clove oil were measured in the same way as above. However, if the setting at the surface and in the inside of the sample progressed differently, the latter was regarded as an index of the setting.

2) Influence on the sealing ability-The sealing ability of the mixture of powder containing rosin and clove oil was determined. The same dye penetration test as mentioned before was performed for the estimation of the sealing ability.

3. Viscosity of the sealer

1) Materials-Following Grossman's preparation, and based upon the results of some basic examinations, the composition of the new sealer was decided as shown in Table 7 . This sealer is denoted as K-20. For comparison, five commercial products for root canal 


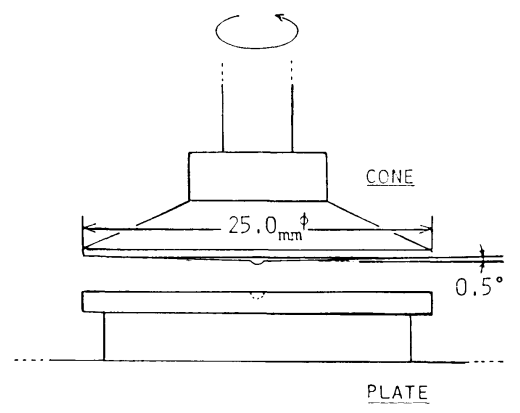

Figure 2 Schematic diagram of the measuring system

filling was employed, namely, Canals, Dentalis KEZ and N2 Universal for a sealer type and Kri-1 and Vitapex as a paste type (Table 8).

2) Measurement of viscosity-Viscosity of the sample was measured with a rotational viscometer, Rheomat 30 (Contraves AG, Swiss). The measuring system consisted of a cone and a plate (Fig. 2). The sample placed between these components is kept at a certain temperature by circulating water through the plate and moisture by covering with a glass cover. The change of viscosity in time was measured in $0.047 \mathrm{rpm}$ of the revolution rate of the cone, namely, $0.167 / \mathrm{sec}$ in shear rate. This method saves the amount of sample and permits examination at a condition close to that of clinical usage.

Influences of the powder/liquid ratio, temperature and moisture on the viscosity were also investigated. They were measured at $20^{\circ} \mathrm{C}, 25^{\circ} \mathrm{C}, 30^{\circ} \mathrm{C}$ and $37^{\circ} \mathrm{C}$, and also in various $\mathrm{P} / \mathrm{L}$ ratios which were equivalent to $0.11,0.13,0.15 \mathrm{ml}$ of liquid for $0.5 \mathrm{~g}$ of powder, with and without moisture.

\section{RESULTS}

1. Effect of heat treatment of $\mathrm{ZnO}$

1) Influence on the setting time

The setting time of the mixture of $\mathrm{ZnO}$ and clove oil increases with the heating temperature of $\mathrm{ZnO}$, especially above $700^{\circ} \mathrm{C}$ (Fig. 3 and Table 3).

For all mixtures, it was difficult to obtain a creamy paste because of the low fluidity and the lack of smoothness due to the presence of large particles, especially when using powder heated at high temperatures $(\mathrm{ZnO}(1000)-\mathrm{ZnO}(1300))$. The setting progressed simultaneously in the whole parts of the sample, and the surface of the final set became coarse and dull.

2) Influence on the sealing abiilty

The sealing ability of mixtures containing powder heated under $900^{\circ} \mathrm{C}(\mathrm{ZnO}(\mathrm{JP})-\mathrm{ZnO}$

Canals (Showa Shizai Kako Co., Ltd. Japan)

Dentalis KEZ (Neo Dental Chemical Products Co., Ltd. Japan)

N2 Universal (AGSA Swiss)

Vitapex (Neo Dental Chemical Products Co., Ltd. Japan)

Kri-1 (Pharmachemie AG Swiss) 


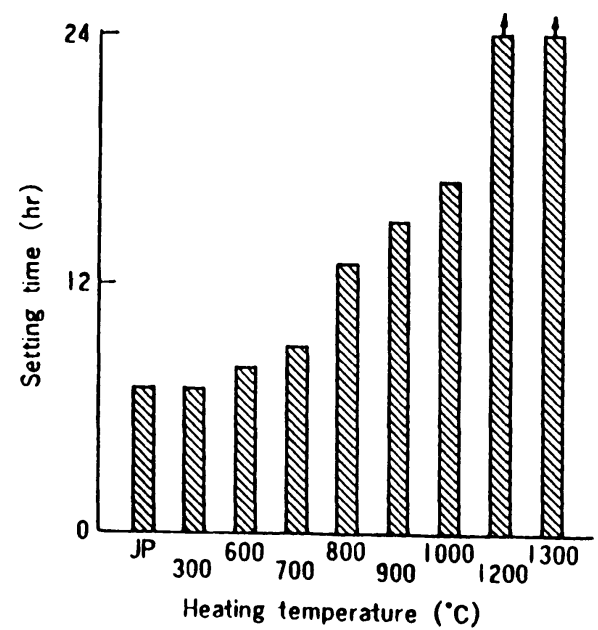

Table 3 Effect of heat treatment of $\mathrm{ZnO}$ on the setting time

\begin{tabular}{cc}
\hline $\begin{array}{c}\text { Heating } \\
\text { Temperature* } \\
\left({ }^{\circ} \mathrm{C}\right)\end{array}$ & $\begin{array}{c}\text { Settins } \\
\text { Time } \\
\text { (hour) }\end{array}$ \\
\hline $\begin{array}{c}\text { Non-heated } \\
300\end{array}$ & 7.0 \\
600 & 7.0 \\
700 & 8.0 \\
800 & 9.0 \\
900 & 13.0 \\
1000 & 15.0 \\
1200 & 17.0 \\
1300 & 25.0 \\
\hline
\end{tabular}

Figure 3 Effect of heat treatment of $\mathrm{ZnO}$ on the

(* Heating Time: 1 hour) setting time

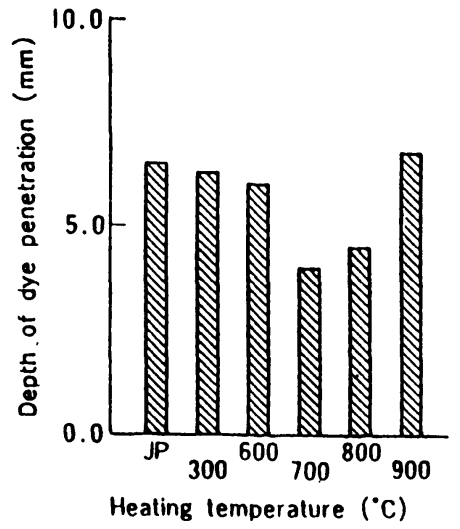

Table 4 Effect of heat treatment of $\mathrm{ZnO}$ on the sealing ability

\begin{tabular}{cc}
\hline $\begin{array}{c}\text { Heating } \\
\text { Temperature* } \\
\left({ }^{\circ} \mathrm{C}\right)\end{array}$ & $\begin{array}{c}\text { Dye } \\
\text { Penetration } \\
(\mathrm{mm})\end{array}$ \\
\hline Non-heated & 6.5 \\
300 & 6.3 \\
600 & 6.0 \\
700 & 4.0 \\
800 & 4.4 \\
900 & 6.7 \\
\hline & (* Heating Time: 1 hour)
\end{tabular}

Figure 4 Effect of heat treatment of $\mathrm{ZnO}$ on the sealing ability

(900)), which formed a rather smooth paste, varies with the heating temperature (Fig. 4 and Table 4). As shown in the figure, with inrceasing heating temperature the sealing ability improves until $700^{\circ} \mathrm{C}$ and deteriorates again above it.

Therefore, $700^{\circ} \mathrm{C}$ was regarded as the optimal temperature for the heating treatment of $\mathrm{ZnO}$ powder.

2. Effect of content of rosin

1) Influence on the setting time

The setting time of the mixture changes according to the content of rosin (Fig. 5 and Table 5). The setting delayed remarkably by adding a small amount $(5-15 \%)$ is conversely accelerated by adding more than $30 \%$.

The fluidity of mixture during mixing procedure also depended on the content of rosin. The $\mathrm{P} / \mathrm{L}$ ratio was fixed a constant value $(3 \mathrm{~g} / \mathrm{ml})$ in all samples for convenience. The mix- 


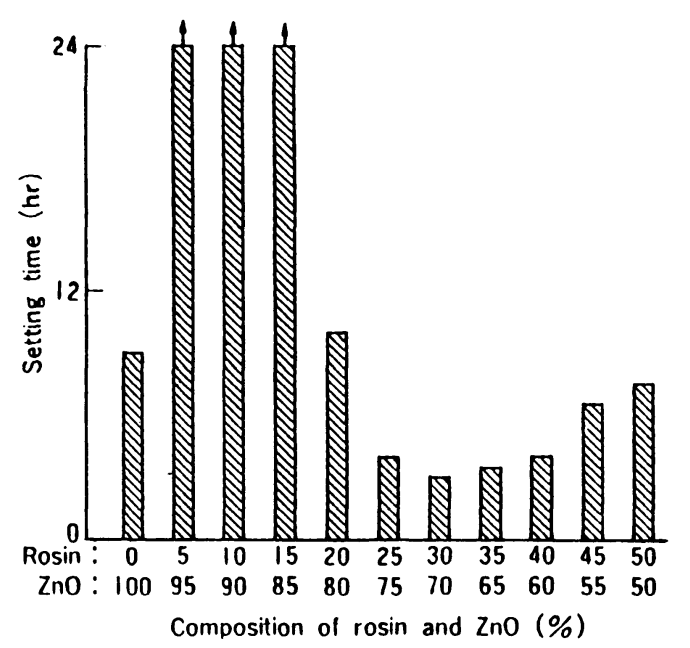

Table 5 Effect of rosin on the setting time

\begin{tabular}{rcc}
\multicolumn{2}{c}{$\begin{array}{c}\text { Composition } \\
(\%)\end{array}$} & $\begin{array}{c}\text { Setting } \\
\text { Time } \\
\text { (hour) }\end{array}$ \\
\hline 100 & Rosin & 9.0 \\
95 & 5 & 3 days \\
90 & 10 & 4 days \\
85 & 15 & 2 days \\
80 & 20 & 10.0 \\
75 & 25 & 4.0 \\
70 & 30 & 3.0 \\
65 & 35 & 3.5 \\
60 & 40 & 4.0 \\
55 & 45 & 6.5 \\
50 & 50 & 7.5 \\
\hline
\end{tabular}

Figure 5 Effect of rosin on the setting time

ture containing $5 \%$ had a low viscosity and became a fluid. Mixtures containing of 10 or $15 \%$ exhibited two types of fluidity which were contrary to each other, namely, they resisted strongly to a rapid application of force such as mixing though they possessed fluidity. This phenomenon is considered to correspond to "dilatancy". In the range of content above $20 \%$, the abnormal flow disappeared. The viscosity of paste increased with the content of rosin, and it ocnsequently prevented the mixing operation above $40 \%$.

The setting of the mixture containing rosin progressed faster at the surface than in the inside of the sample. This tendency was especially apparent for samples containing rosin above $30 \%$ which set rapidly. The surface of the final set containing it above $10 \%$ appeared like to be coated with a glossy film and had a finer texture than that containing $5 \%$ or none.

2) Influence on the sealing ability

The dye penetration into the sample decreases, namely, the sealing ability increases

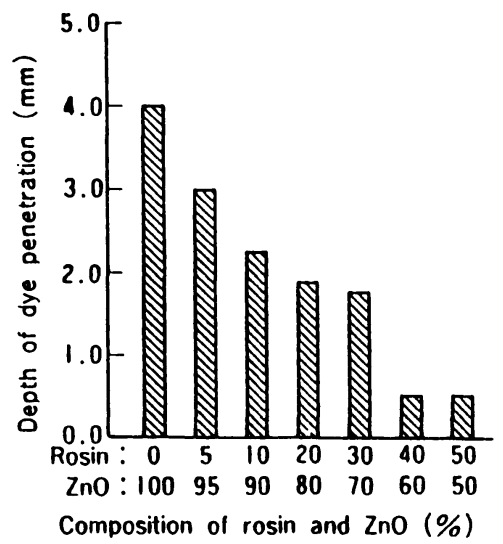

Table 6 Effect of rosin on the sealing ability

\begin{tabular}{ccc}
\hline \multicolumn{2}{c}{$\begin{array}{c}\text { Composition } \\
(\%)\end{array}$} & $\begin{array}{c}\text { Dye } \\
\text { Penetration } \\
(\mathrm{mm})\end{array}$ \\
\hline 100 & 0 & 4.0 \\
95 & 5 & 3.0 \\
90 & 10 & 2.2 \\
80 & 20 & 1.9 \\
70 & 30 & 1.8 \\
60 & 40 & 0.5 \\
50 & 50 & 0.5 \\
\hline & $\left(*\right.$ Heated at $700^{\circ} \mathrm{C}$ for 1 hour $)$
\end{tabular}

Figure 6 Effect of rosin on the sealing ability 
with the content of rosin (Fig. 6 and Table 6). Little penetration was observed in samples which contained it above $40 \%$.

3. Viscosity of the sealer

All commercial products including K-20 can be divided into two groups by the difference of the viscosity change with time (Fig. 7). The value appended to the end of solid curve line indicates time required for reaching to the measurable maximum of this system from the start of mixing. The viscosity of the sealer type to which KEZ, N2, CA and K-20 belong increases suddenly after a certain point. On the contrary, the values of the paste type, KRI and VPX, remained constant or decreasing slightly. The sudden increase of viscosity of K-20 arises later than the other sealer type materials.

The viscosity-time curve of K-20 shifted to the left and increases sharply with temperature (Fig. 8). The same tendency is also seen as the $\mathrm{P} / \mathrm{L}$ ratio decreases or as humidity increases (Fig. 9).

Table 7 Composition of K-20

$\begin{array}{ll}\text { Powder } & \\ \text { Zinc oxide, heated at } 700^{\circ} \mathrm{C} & 39 \mathrm{wt} \% \\ \text { Rosin } & 30 \\ \text { Bismuth subcarbonate } & 15 \\ \text { Barium sulphate } & 15 \\ \text { Chlorhexidine dihydrochloride } & 1\end{array}$

Liquid

Eugenol

Peanut oil
Table 8 I ist of materials used in the measurement

$\begin{array}{ll}\text { K-20 } & (\text { K20) } \\ \text { Canals } & (\mathrm{CA}) \\ \text { N2 } & (\mathrm{N} 2) \\ \text { Dentalis KEZ } & (\text { KEZ) } \\ \text { Vitapex } & (\mathrm{VPX}) \\ \text { Kri-1 } & (\mathrm{KRI})\end{array}$

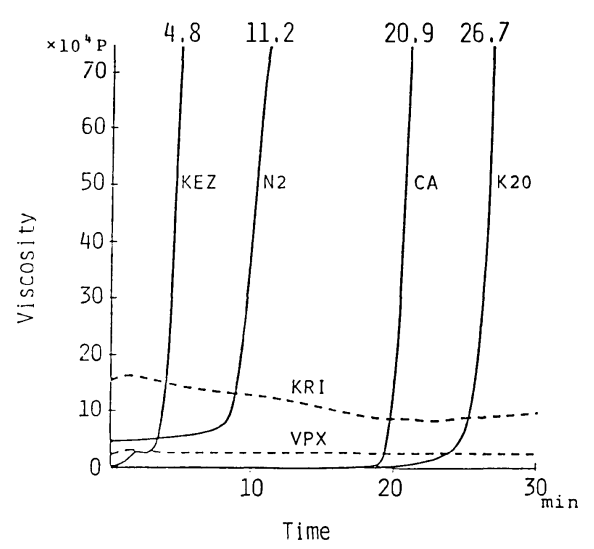

Figure 7 Comparison of the viscosity change of $\mathrm{K}-20$ with five commercial products

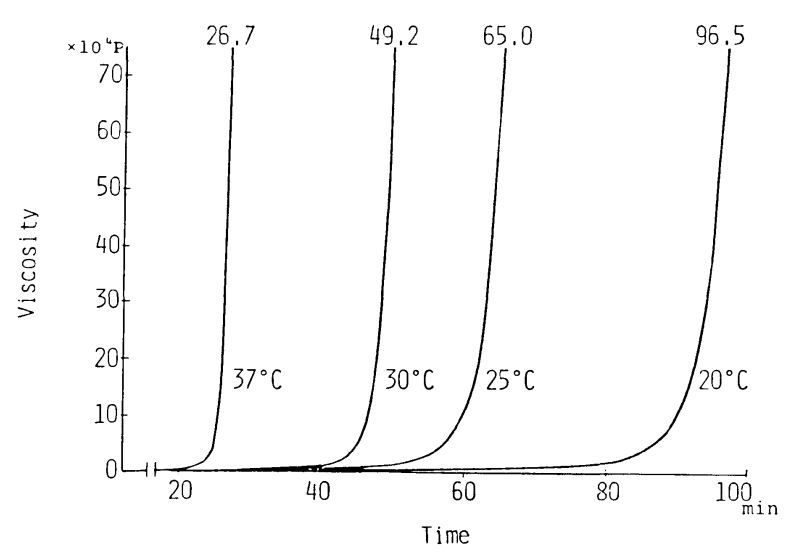

Figure 8 Effect of temperature on the viscosity change of $\mathrm{K}-20$

\section{DISCUSSION}

1. Effect of heat treatment of $\mathrm{ZnO}$

Since the root canal sealer investigated in this report belongs to the $\mathrm{ZnO}$-eugenol 


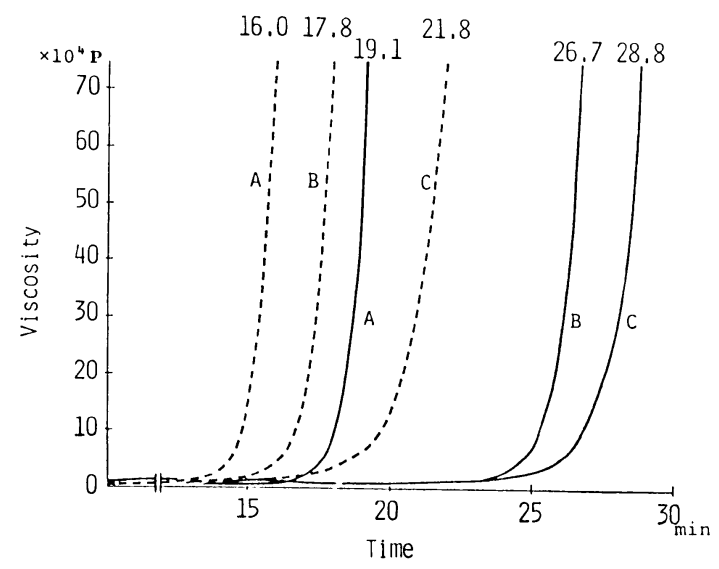

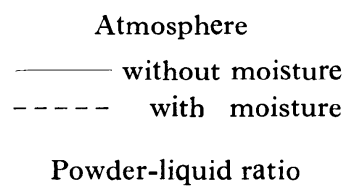

A: $0.5 \mathrm{~g} / 0.15 \mathrm{ml}$

B: $0.5 \mathrm{~g} / 0.13 \mathrm{ml}$

C: $0.5 \mathrm{~g} / 0.11 \mathrm{ml}$

Figure 9 Effects of moisture and $\mathrm{P} / \mathrm{L}$ ratio on the viscosity change of $\mathrm{K}-20$

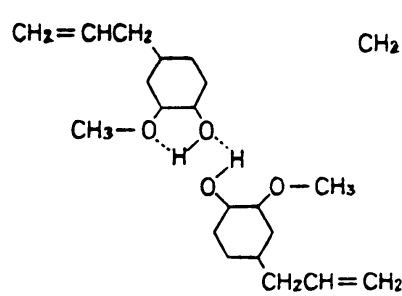

(a)

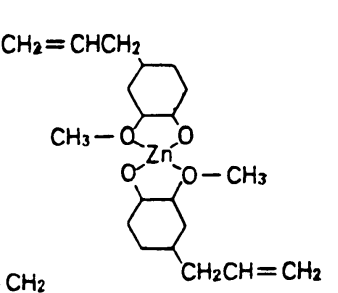

(b)

Figure 10 Dimer of eugenol (1) and zinc eugenolate chelate (b)

system, the setting process appears to depend on the chelating reaction between $\mathrm{ZnO}$ and eugenol ${ }^{6}$. Eugenol is dimerized by an intra- and an intermolecular hydrogen bond (Fig. 10a), and zinc eugenolate is formed when it reacts with a zinc ion (Fig. 10b). In this reaction, physical or physicochemical property of the surface of $\mathrm{ZnO}$ particle is presumed to be one of the important factors which control the progress of the reaction.

$\mathrm{ZnO}$ powder employed in this study was obtained from the ground metal of $\mathrm{Zn}$ (m.p. $419^{\circ} \mathrm{C}$ ) melted at about $1000^{\circ} \mathrm{C}$, oxidized and cooled by blowing preheated air, namely, by the direct method. It has been found that an excess of zinc remains stoichiometrically in the newly prepared particles of $\mathrm{ZnO}^{7}$, and the lattice of crystal may also be distorted due to the rapid cooling. Though the activity of $\mathrm{ZnO}$ is affected by the presence of these impurities and lattice defects, it is almost impossible to control these factors in the process of the production of $\mathrm{ZnO}$ and to obtain a powder possessing a constant activity. In addition, the bulk of the powder consisting of small particles contains water adsorbed by the large specific surface and permeating into the many spaces between particles. According to the previous report that the setting reaction of $\mathrm{ZnO}$-eugenol system was activated in the presence of water ${ }^{8)}$, the setting time may vary widely by the change of water absorption due to the difference of the storage condition.

The heating treatment of $\mathrm{ZnO}$ is indispensable for improving the irregularity of powder to accomplish a stable activity. In this study an optimal condition of the heating treatment 


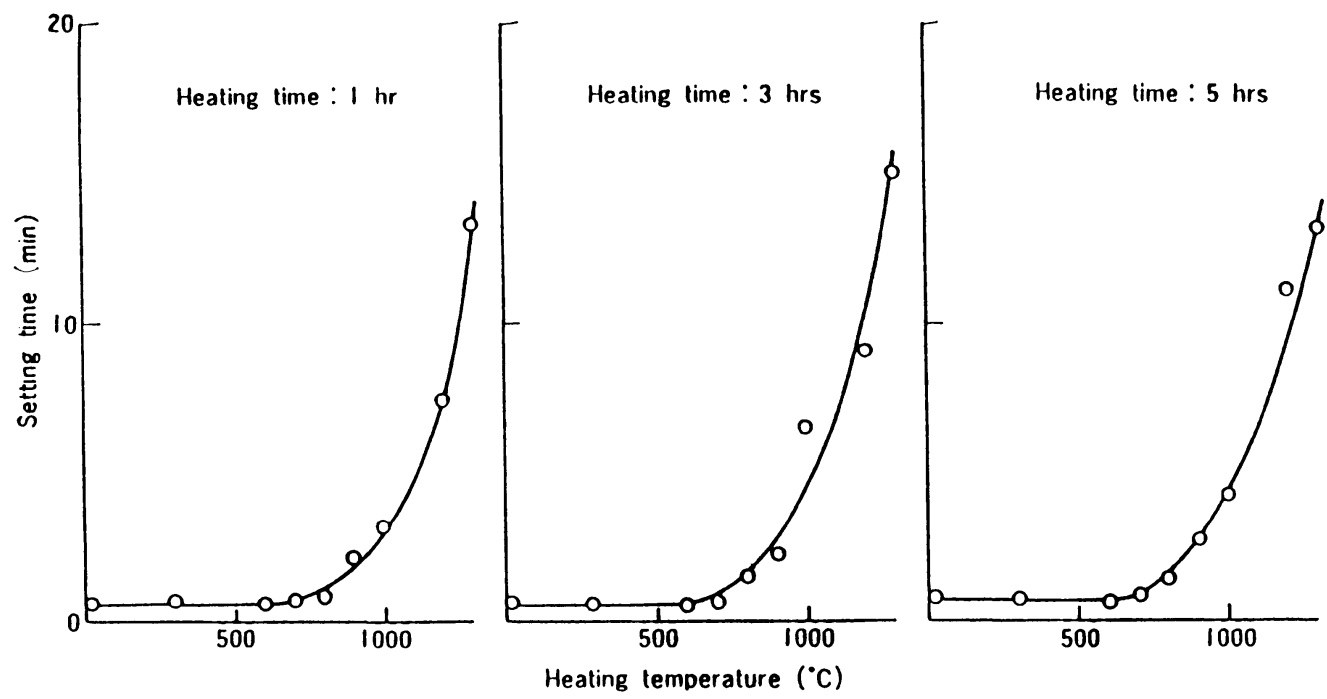

Figure 11 Effect of heat treatment of $\mathrm{ZnO}$ on the setting time of mixture with polycarboxylate solution

of $\mathrm{ZnO}$ as a component of a sealeı was determined by means of the measurements of the setting time and the sealing ability which are also the important clinical properties. From the results on the setting time, no difference was observed among heating temperatures under $600^{\circ} \mathrm{C}(\mathrm{ZnO}(\mathrm{JP})-\mathrm{ZnO}(600))$, however, it increases markedly with temperature above $700^{\circ} \mathrm{C}(\mathrm{ZnO}(700)-\mathrm{ZnO}(1300))$. It was found that the activity of $\mathrm{ZnO}$ to eugenol is reduced rapidly contrary to the increase of heating temperature above $700^{\circ} \mathrm{C}$.

This tendency is also evident in the experiment which was performed using the mixture of heated $\mathrm{ZnO}$ and a solution of carboxylate (the liquid of Shofu HY-BOND CARBOCEMENT) (Fig. 11). In addition, the influence of the holding time (1, 3 and 5 hours) at a certain temperature on the setting time was also evaluated, but no apparent distinction was noted.

The activity of $\mathrm{ZnO}$ is remarkably affected by the alteration of the physicochemical property of the surface of particle induced by sintering in the heat treatment. Adjacent particles fuses together resulting in a stable state with a low surface energy. With the formation of lrager individual particles, the specific surface area of powder decreases causing a reduction in contact of powder and liquid during the mixing procedure, and delaying setting time. The reduction of adsorbed water by the decrease of surface area and the advance of oxidation of zinc remaining unreacted are also considered to retard the setting reaction.

The shape of particles of $\mathrm{ZnO}(\mathrm{JP})-\mathrm{ZnO}(1300)$ was observed by SEM (Fig. 12a-i). No apparent difference in the size and shape was detected between $\mathrm{ZnO}(\mathrm{JP})$ and $\mathrm{ZnO}(300)$, namely, both of them consist of fine, rod-shaped particles, which show the characteristic of a crystal of $\mathrm{ZnO}$, reaching less than $0.5 \mu \mathrm{m}$ in length and $0.2 \mu \mathrm{m}$ in width. In $\mathrm{ZnO}$ (600), however, many particles grow above $0.5 \mu \mathrm{m}$ and present an indefinite or a roundish shape by the fusion. With growing to $0.5-1.0 \mu \mathrm{m}$, the particles of $\mathrm{ZnO}(700)$ and $\mathrm{ZnO}$ (800) become almost uniform in size and round. With high temperatures of the treat- 



Figure 12 SEM photographs of the powder of $\mathrm{ZnO}$ heated at various temperatures
a: JP b: $300^{\circ} \mathrm{C}$
c: $600^{\circ} \mathrm{C}$
d: $700^{\circ} \mathrm{C}$ e: $800^{\circ} \mathrm{C}$
f: $900^{\circ} \mathrm{C}$
g: $1000^{\circ} \mathrm{C}$ h: $1200^{\circ} \mathrm{C}$
i: $1300^{\circ} \mathrm{C}$ 
ment, the particle size increases markedly and the shape changes from the roundish to the indefinite again. The smoothness of mixing can not be achieved by using of these coarse and irregular particles of $\mathrm{ZnO}(1200)$ and $\mathrm{ZnO}(1300)$. The results obtained in this study that include the decrease of the activity of $\mathrm{ZnO}$ heated above $600^{\circ} \mathrm{C}$ and the observation by SEM agree with the previous report that the sintering of a newly proudct of $\mathrm{ZnO}$ occurs above $700^{\circ} \mathrm{C}^{9}$. Although the heat treatment is an indispensable process for the preparation of $\mathrm{ZnO}$ powder, the excessive heating must be inappropriate as resulting in the absurd delay of setting reaction because its activity to eugenol is inherently low.

Next, in the dye penetration test of the mixture of heated $\mathrm{ZnO}$ and eugenol, the best sealing ability exhibited as the least dye penetration is obtained by using $\mathrm{ZnO}(700)$. As the chelate of the central $\mathrm{Zn}$ ion and eugenol legands, which is responsible for the setting of $\mathrm{ZnO}$-eugenol system, exists in equilibrium depending on a definite stability constant, the final set contains some free eugenol ${ }^{10}$. When it is immersed in the dye solution, the equilibrium is disturbed by the transudation of free eugenol still it has a low solubility $(0.02 \%)$. Consequently, the set is decomposed by hydrolysis of zinc eugenolate, and it deteriorates the sealing ability. As is shown in Table 2, the lower the heating temperature of $\mathrm{ZnO}$ is, the more the mixture contains eugenol to gain a certain consistency, and then the more the dye penetrates. On the other hand, with $\mathrm{ZnO}$ heated above $600^{\circ} \mathrm{C}$ the setting reaction is delayed and the amount of unreacted free eugenol increases. Therefore the sealing ability of the mixture improves with heating temperature until $700^{\circ} \mathrm{C}$ but declines above it.

\section{Effect of content of rosin}

Rosin is a yellowish or a brownish bulk possessing glasslike transparency and is obtained by evaporation to dry residual resin which is formed after removing spirit from turpentine by distillation in vacuum or in steam. Owing to characteristic such as surface activity, film formation and tackiness, it is widely used in various fields, for example, sizing of paper, an emulsifier in polymerization of synthetic rubber, and in varnish or tackifiers. A chemical component of rosin consists of resinous acids (about 90\%) and neutral substances (about $10 \%$ ). These acids are composed as a combination of nearly ten kinds of isomer belonging to diturpenic resinous acid, which has 20 carbons in the structure (Fig. 13).

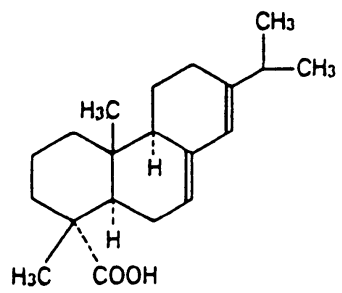

Figure 13 Abietic acid

The influences of rosin added to the mixture of $\mathrm{ZnO}(700)$ and clove oil on the setting time and the sealing ability were investigated. The setting time changes depending on the content of rosin, namely, it increases markedly the rosin content was $5-15 \%$ and recovers 
or becomes shorter for $25-30 \%$ in comparison with that containing no rosin; however, it increases again above $35 \%$. Fluidity and setting progress of the mixture, and surface texture of the final set also varied with the content of rosin.

It is considered that on account of adding of rosin clove oil permeates sufficiently into the space of particles of $\mathrm{ZnO}$ and increases the affinity of these two components. Because the isomers of rosin include both hydrophobic methyl and aromatic groups and hydrophilic carboxyl group in the structure (Fig. 13), the wetting of powder seems to be improved by its surface activity. From the specific rheological behaviours such as dilatancy and spinnability of the mixture containing rosin, some weak interactions are supposed to occur among $\mathrm{ZnO}$, rosin and eugenol. With increasing of rosin dissolved in clove oil, the viscosity of mixture rises by its cohesiveness. The excess of rosin, however, makes the mixing operation difficult and may produce unsoluble particles which affect negatively the manipulation and some properties of the mixture.

The reduction of setting time is found with the mixture containing rosin above $20 \%$. The setting of these mixture begins at the surfcae exposed to the air and advances faster than that of the inside. On the other hand, it advances almost simultaneously in all parts of the mixture containing lower than $10 \%$. This result proves that in addition to the effect of the moisture, the sufficient amount of rosin accelerates the setting reaction of $\mathrm{ZnO}$ and eugenol due to its film forming ability. As the surfaces of the final sets containing rosin above $20 \%$ become finer and harder than that of containing lower than $10 \%$, the former are considered to have a superior property to the latter. The fact is in agreement with the previous report that the solubility of $\mathrm{ZnO}$-eugenol cement is improved by adding of $\operatorname{rosin}^{11)}$.

The effect of rosin on this process is so great that the mode of setting of $\mathrm{ZnO}$-eugenol system as a sealer is considered to be based not only on the chelation of $\mathrm{ZnO}$ and engenol but also on the reaction including rosin. Such relation between $\mathrm{ZnO}$ and rosin is also found in the usage of $\mathrm{ZnO}$ as a hardener of varnish. The interaction between $\mathrm{ZnO}$ and active carboxyl group of the isomeric resinous acids as the principal components of rosin is one of the factors organizing the mechanism of setting of the sealer.

In the low concentration, the setting is delayed and no film is formed because of lack of absolute amount of rosin in spite of the improvement of affinity of $\mathrm{ZnO}$ and clove oil. With increasing of rosin, the reaction progresses and the film is formed especially at the surface of samples. Rosin is an important component of the sealer because its film forming ability is related directly to the situation of clinical usage of the sealer.

Next, the sealing ability is apparently improved with increasing of rosin, namely, the porosity of the mixture is reduced by the close contact of powder and liquid due to the addition of rosin. The effect increases with reduction of the setting time and increase of cohesiveness. To add the excess of rosin, however, will be inappropriate for the clinical usage as the manipulation and flow of the mixture are deteriorated. These results confirm Grossman's preparation which contains $30 \%$ of rosin as a proper composition for the new sealer.

3. Viscosity of the sealer

The setting process of a root filling material can be estimated as change of its viscosity 
with time. The viscosity of the material is also an important factor affecting the operational property in its clinical use. For this reason, it is considered to be profitable to determine the viscosity of the material. The measuring system, a cone and plate system, employed in this study is especially advantageous as follows: the specimen can be measured in the form of a thin layer which corresponds to the clinical use and makes the amount of sample small.

As all three commercial products of sealer type and K-20 belong basically to $\mathrm{ZnO}$ eugenol system, they pursue a similar course of the change of viscosity. The sudden increase of viscosity appears with difference in time probably due to the variety of composition, for example, the content of rosin and the heat treatment of $\mathrm{ZnO}$ as mentioned before or the additive such as activator. From a clinical point of view, the period of the low viscosity must be sufficiently long to obtain a proper operation time. For this reason, the rising of viscosity of KEZ may occur too fast to fill a complicated root canal.

The viscosity change of $\mathrm{ZnO}$-eugenol (clove oil) mixture was also determined to compare with $\mathrm{K}-20$ as one of the sealer type material. As is presented schematically in Fig. 14, a remarkable difference is found between their aspects in spite of the fact that they belong basically to the same group. It is considered to confirm the previous finding that the setting reaction is concerned not only with the interaction between $\mathrm{ZnO}$ and eugenol but with the effect of rosin. The property of a film formation of rosin seems to appear more clearly in the shape of the thin layer of a sample used in this measuring system than in the bulk used in the previous experiment.

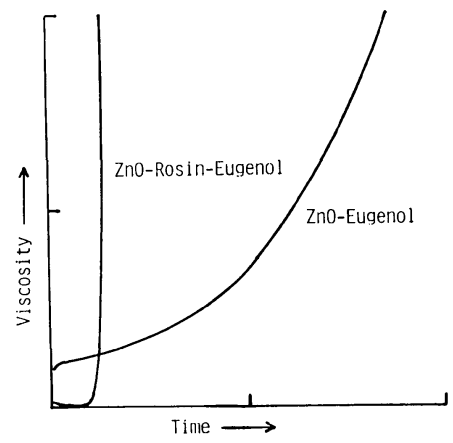

Figure 14 Effect of rosin on the viscosity change of $\mathrm{ZnO}$-eugenol mixture

Temperature of a sample may be controlled accurately because it is attached directly to the plate in which water of a constant temperature circulates. The viscosity change is accelerated with temperature (Fig. 8). The influence of temperature is so great that the setting of the sealer in a clinical use may progress with a large difference in time between the inside and the outside of the mouth.

Humidity and the $\mathrm{P} / \mathrm{L}$ ratio also affect this process. It progresses faster as the $\mathrm{P} / \mathrm{L}$ ratio becomes lower, and with moisture than without it if the ratio is the same (Fig. 9). As water promotes the setting reaction of $\mathrm{ZnO}$-eugenol system, the finding about the influence of humidity is in agreement with it. The influence of the $\mathrm{P} / \mathrm{L}$ ratio, however, shows 
a tendency contrary to that obtained generally about the other dental cements. In the components of the powder of $\mathrm{K}-20$, only rosin is highly soluble in clove oil and consequently may show some specific properties such as tackiness or film forming ability. From this reason, the dissolved rosin is considered to have a large influence to the setting reaction. In the high $\mathrm{P} / \mathrm{L}$ ratio the amount of rosin to a certain volume of clove oil increases excessively, and it may make the mixture become more viscous, disturbing the uniformity of the sealer and reducing sufficient contact between $\mathrm{ZnO}$ and rosin. This behaviour of rosin agrees with the former determination about the relation between the content of rosin and the setting time of $\mathrm{ZnO}$-rosin-clove oil mixture.

\section{CONCLUSIONS}

The influences of the heat treatment of $\mathrm{ZnO}$ and the content of rosin on the setting time and the sealing ability of the sealer belonging to $\mathrm{ZnO}$-eugenol system was investigated. The conclusions are obtained as follows:

1) The setting time of $\mathrm{ZnO}$-eugenol mixture is remarkably increased by using $\mathrm{ZnO}$ heated above $700^{\circ} \mathrm{C}$. The resulting increase in particle size by sintering is confirmed to occur above $600^{\circ} \mathrm{C}$ by SEM observation. The setting reaction is considered to be retarded by the reduction of the specific surface area, the adsorbed water and the amount of zinc remained stoichiometrically. However, the excessive heat treatment must be avoided to ensure the adequate setting time.

2) The best sealing ability is obtained by using of the mixture containing $\mathrm{ZnO}(700)$. This property seems to be improved with reducing of free eugenol remained in the mixture or the final set. From this result, the optimal heating temperature of $\mathrm{ZnO}$ is regarded as $700^{\circ} \mathrm{C}$.

3) By adding of rosin, the mixture becomes viscous. With increasing of the content of rosin, the setting time increases remarkably for $5-15 \%$, recovers to the minimum for $30-35 \%$ and prolongs slightly again above $40 \%$.

4) The sealing ability is improved with increasing of rosin. However, from the point of view of the cliniacl manipulation, the mixture with a high viscosity is inappropriate as a sealer.

5) Viscous behavior of the sealer, called K-20, consisting of the composition fixed by the former experiment was compared with some commercial products for the root filling. K-20 shows the same tendency of the viscosity change with time as that of other sealer type materials. K-20 has a sufficient time for the clinical manipulation and sets sharply after the operation finished.

6) The increase of viscosity appears faster as temperature becomes higher. It suggests that there is a large difference of the advance of setting in time between the inside and the outside of the mouth.

7) Humidity also promotes the appearance of viscosity change. However, the increase of the $\mathrm{P} / \mathrm{L}$ ratio retards it. It is supposed that in the high $\mathrm{P} / \mathrm{L}$ ratio the viscosity of the mixture becomes excessively large to reduce the sufficient contact of each component.

From those results, the appropriate composition for the new sealer was confirmed qualitatively and quantitatively. The real product consisting of this composition was ex- 
amined about some properties. The investigation of the antimicrobial activity will be reported in the next paper.

\section{ACKNOWLEDGEMENTS}

The author wish to thank Dr. Kazuo Ida and Dr. Yoshiaki Tani for many helpful suggestions during the course of this work, and also wish to thank the staffs of Department of Dental Materials, Research Center for Medical Polymers and Biomaterials, Kyoto University for their kindness cooperations.

\section{REFERENCES}

1) Grossman, I.L.: Endodontic Practice, 10th ed., Lea \& Febiger, 1981, 297

2) Prosser, H.J. and Wison, A.D.: Zinc oxide eugenol cements. VI. Effect of zinc oxide type on the setting reactions, J. Biomed. Mat. Res., 16, 585-598, 1982

3) Sina, S., Mitomo, K., Hatogai, N., Takahashi, H., Nakagawa, K., Okada, T., Ito, A., and Asai, Y.: Experimental Studies on the Sealing Properties of Various Kinds of Root Canal Sealers and Pastes in vitro, with Special Reference to Zinc Oxide Eugenol Preparations, The Shikwa Gakuho, 80 (3), 473-485, 1980 (in Japanese)

4) Nagasawa, W. and Hirata, E.: The sealing properties of root-canal filling agents, The Nippon Dental Review, 405, 34-41, 1976 (in Japanese)

5) Grossman, L.I.: Physical properties of root canal cements, J. Endod., 2(6), 166-175, 1976

6) Wilson, A.D., Clinton, D.J. and Miller, R.P.: Zinc Oxide-eugencl Cements: IV. Microstructure and Hydrolysis, J. dent. Res., 52(2), 253-260, 1973

7) Kato, E. Naka, S. and Noda, T.: Chemistry of Inorganic Materials I, 2nd ed., CORONA PUBLISHING CO., LTD., 1975, 42 (in Japanese)

8) Batchelor, R.F. and Wilson, A.D.: Zinc Oxide-Eugenol Cements: I. The Effect of Atmospheric Conditions on Rheological Properties, J. dent. Res., 48(5), 883-887, 1969

9) Lee, V.J. and Parravano, G.: Sintering Reactions of Zinc Oxide, J. Appl. Phys., 30, 1735-1740, 1959

10) Wilson, A.D. and Batchelor, R.F.: Zinc Oxide-Eugenol Cements: II. Study of Erosion and Disintegration, J. dent. Res., 49(3), 593-598, 1970

11) Brauer, G.M., Simon, L. and Sangermano, L.: Improved zinc oxide-eugenol type cement, J. dent. Res., 41(5), 1096-1102, 1962 


\section{クロルヘキンジン塩酸塩を配合した 抗菌性根管充填用ンーラーに関する研究}

第 1 報 ベースとなるシーラーの組成の影響について

南部敏之

京都大学医用高分子研究センター歯科材料応用研究部門

酸化亜鉛ユージノール系のシーラーについて, 酸化亜 鉛の熱処理やロジンの配合量の違いが，硬化時間と封鎖 性に与える影響を検討した。酸化亚鉛とチョウジ油の練

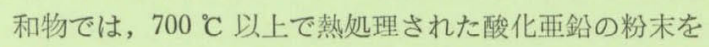
用いた場合, 急激に硬化時間が延長した。また処理温度 700 ○ の粉末を用いた場合に封鎖性は最あ良くなった。 この練和物へのロジン配合率について，5１5\%の場合 硬化時間は延長したが, 配合率が増加するにつれ短 縮
し，30\%で最小值となった。この傾向は硬化機序におけ るロジンの影響が大きいととを示唆している。封鎖性は 配合率の増加につれ良くなったが, 臨床におりる操作性 の点で, 過大な粘着性をむつ配合率40\%以上のものは実 用的ではない。これらより抗菌性を持つシーラーのベー スとしての酸化車鉛ユージノール系シーラーは, 700 ㅇ で熱処理した酸化业鉛を含み，ロジンが30\%配合されて いるものが適しているといえる。

\section{X線による高溶卑金属合金鋳造体の非破壊検査}

川原春幸, 石崎順啓, 前田孝俊, 栄 弘毅

\section{大阪歯科大学歯科理工学教室}

コバルト・クロム系扰よびニッケル・クロム系合金は 耐食性にすぐれ機械的強度も大きく軽量で, しかす生体 組織へのなじみあ良好である。さらに精密鋳造成形法に ついてあほぼ確立され, 比較的精度の良い鋳造体が得ら れるようになってきた。最近では鋳造床のみならずクラ ウンーブリッジ，メタルボンドポーセレンさらにインプ ラント用として広く活用されようとしている。しかしこ の種の合金には鋳造欠宿が多発するという大きな難点が ある。とくに内部鋳造欠宿の発生は鋳造成形物の機械的 性質や耐食性を著しく低下させ生物学的にも種々の問題 を包含している。そてで鋳造体内部の欠陷の発生機構を 解析し, 欠陥防止法を究明するために菌科鋳造体専用の X線装置を開発し，その性能を調べるととあにいくつか の実験を行ってみた。すなわち,コバルト・クロム合金 (Bionium) およびニッケル・クロム合金 (Wiron) で鋳 造成形された階段状の test piece を使用した。 test pie- ce の厚径は $0.35 \mathrm{~mm}$ から $4.55 \mathrm{~mm}$ までを $0.35 \mathrm{~mm}$ ご とに13段階にしたものである。なお，臨床実験例として コバルト・クロム合金による鋳造床とクラウン，骨膜下 インプラントの下部構造体などの内部欠陥を観察した。

その結果, 歯科鋳造体専用 X線装置 $(\mathrm{Bio}-\mathrm{X})$ を用い ることによってきわめて鮮明なX線像が得られるととが 分かった。本法によればブローホールや樹枝状鋳巣のよ うな微細な欠陷まで観察が可能で，とくに管電圧 50,60 および $70 \mathrm{KVp}$ で90秒間の嚗写条件でコバルト・クロム 系およびニッケル・クロム系合金鋳造体内部のほとんど の欠陥が観察された。

以上のととから，X線による金属鋳造体の非破壊検査 は臨床上非常に有用なあのであるととが理解できた。と くに鋳造性能のよくない高溶龵金属金鋳造体については 臨床応用以前における必須の検查法として採用すべきで あろう。

DSC 等温法飞よるジメタクリレートモノマーの重合発熱の研究

伴 清治, 長谷川二郎

愛知学院大学歯学部歯科理工学教室 